TEME, г. XLIII, бр. 4, октобар - децембар 2019, стр. 931-956

\begin{tabular}{lr}
\hline \hline Оригинални научни рад & https://doi.org/10.22190/TEME190918056S \\
Примљено: 18. 9. 2019. & UDK 343.1:343.9.02(497.6)"2015/2018"
\end{tabular}

Ревидирана верзија: 18. 9. 2019.

Одобрено за штампу: 1. 12. 2019.

\title{
ADEQUACY OF PENAL POLICY IN CRIMINAL CASES OF ORGANIZED CRIME
}

\author{
Miodrag Simović ${ }^{1}$, Mile Šikman ${ }^{2}$ \\ ${ }^{1}$ Constitutional Court of $\mathrm{BiH}$ and \\ University in Banja Luka, Faculty of Law, Banja Luka, Bosnia and Herzegovina \\ ${ }^{2}$ Ministry of Interior of Republika Srpska and \\ University in Banja Luka, Faculty of Law, Bosnia and Herzegovina \\ *vlado_s@blic.net
}

\begin{abstract}
Organized crime is a serious form of crime, whether it is viewed in the criminological sense or as the criminal justice response to this phenomenon. In this regard, the penal policy of the legislator should be proportionate to the gravity of organized crime. However, the penal policy of the courts does not reflect the stated intentions, which is primarily reflected in relatively mild criminal penalties for criminal offenses of organized crime. Although the case law does not contravene the law, i.e. contra legem, because it moves within the boundaries prescribed by the law, it is obvious that the issue is about imbalance of punishment for these criminal offenses, even when it comes to mitigating of the sentence of imprisonment. This paper will provide an analysis of the criminal law framework of organized crime prescribed by the Criminal Code of Bosnia and Herzegovina $(\mathrm{CC} \mathrm{BiH})$, as well as an analysis (statistical and descriptive) of the jurisprudence in the criminal cases of organized crime before the Court of Bosnia and Herzegovina (Court of $\mathrm{BiH}$ ) for the period 2015-2018. As it is not justified and desirable for the legislator's criminal policy and court case jurisprudence to have a different approach in relation to these criminal offenses (different valuation and grading of severity of organized crimes), we will also make certain proposals for de lege ferenda. The paper is a continuation of earlier researches of this problem and is based on the analysis of court judgments in organized crime cases.
\end{abstract}

Key words: $\quad$ organized crime, court case law, penal policy, judgment, analysis.

\section{АДЕКВАТНОСТ КАЗНЕНЕ ПОЛИТИКЕ У КРИВИЧНИМ ПРЕДМЕТИМА ОРГАНИЗОВАНОГ КРИМИНАЛИТЕТА}

\section{Апстракт}

Организовани криминалитет спада у тешке облике криминалитета, било да се посматра у криминолошком смислу или да се говори о кривичноправном реаговању на овај криминални феномен. У том смислу, требало би да казнена политика 
законодавца одговара тежини кривичних дјела организованог криминалитета. С друге стране, казнена политика судова не одражава наведене интенције, што се прије свега огледа у релативно благим кривичним санкцијама за кривична дјела организованог криминалитета. Иако судска пракса не поступа супротно закону, тј. contra legem, jep се креће у границама које су њиме прописане, па чак и кад се ради о ублажавању казне затвора, очигледно је да се ради о дисбалансу кажњавања за ова кривична дјела. У раду ће бити дата анализа кривичноправног оквира организованог криминалитета прописаног Кривичним законом Босне и Херцеговине [КЗ БиХ], као и анализа (статистичка и дескриптивна) судске праксе у кривичним предметима организованог криминалтитета пред Судом Босне и Херцеговине [Суд БиХ] за период 2015-2018. године. Будући да није оправдано и пожељно да казнена политика законодавца и судска пракса имају различит приступ по питању ових кривичних дјела (различито вредновање и степеновање тежине инкриминација организованог криминалитета), даћемо и одређене приједлоге de lege ferenda. Рад представља наставак ранијих истраживања ове проблематике и заснован је на анализи судских пресуда у предметима организованог криминалитета.

Кључне ријечи: организовани криминалитет, судска пракса, казнена политика, пресуда, анализа.

\section{INTRODUCTION}

As the primary purpose of criminal law is to exercise a protective function by prescribing criminal offenses and criminal sanctions for these offenses (Stojanović, 2009, p. 3), through the Criminal Code (Criminal Code of Bosnia and Herzegovina, 2003, 2004, 2005, 2006, 2010, 2014, 2015, 2018 $(\mathrm{CC} \mathrm{BiH}))$, the logical sequence is their application, which is established in criminal proceedings in which a criminal sanction is imposed for the committed criminal offense (Stojanović, 2009, p 3). Therefore, in order to achieve the purpose of punishment ( $\mathrm{CC} \mathrm{BiH}$, Article 39), it is necessary to prescribe appropriate criminal sanctions (type and range of criminal sanctions) based on its proportionality to the severity of threat to personal freedoms and human rights, and other basic values $(\mathrm{CC} \mathrm{BiH}$, Article 2, paragraph 2), as well as their adequate application in criminal proceedings. In this manner, the criminal-political commitment of punishment for certain types of behavior is expressed; that is, the principle of the limiting of criminal coercion is confirmed, thus ensuring its legitimacy ${ }^{1}$.

Organized crime, as a serious form of crime $^{2}$, is present in various forms in Bosnia and Herzegovina $(\mathrm{BiH})$. This is supported by the

\footnotetext{
${ }^{1}$ This principle requires the enforcement of criminal justice protection to the minimum necessary, as well as the use of other adequate means and measures to prevent behaviors that attack the most valuable goods of man and society (Stojanović, 2018, p. 40).

${ }^{2}$ As organized crime understands those forms of criminal offenses that are qualified by more serious circumstances (acts of multiple persons mutually connected, use of violence, etc.) for which a more serious criminal sanction is envisaged (the lowest sentence of certain duration), including sentence of imprisonment and sentence of
} 
assessments of state authorities that characterize organized crime as „, contemporary borderless security threat that threatens the present stage of civilization's development and its achievements and an obstacle to further progress" (Council of Ministers, 2016, p. 4). In addition to that, violent murders related to organized crime have occured in $\mathrm{BiH}$, including the socalled „ordered murders" as a result of the conflicts between organized criminal groups ${ }^{3}$; there has been an increase in the participation of $\mathrm{BiH}$ citizens in international chains of smuggling and trafficking of narcotic drugs; robberies that resulted in the seizure of multi-million property gain ${ }^{4}$ have been recorded; but also, human trafficking, both for sexual and labor exploitation; and, finally, substantial material damage as a consequence of commission of criminal offense of organized crime in economy and finance (Šikman, 2019, p. 370). Also, there is extensive case law on organized crime in $\mathrm{BiH}$ since criminal proceedings have been conducted for these criminal offenses before courts of all levels and jurisdictions from 2003.

However, these issues are not sufficiently clarified in their general sense, and bringing them into connection with particular forms of crime, such as organized crime, further deepens this issue. If we add to this the concept of adequacy that has to be applicable, socially rational and fair in terms of the system of criminal law norms, in order to serve a function of criminal policy (Bejatović, 2012, p. 24), then we have a complex issue whose assessment requires an analysis of the organized crime legislative framework and an analysis of court jurisprudence when it comes to these criminal offenses. The aforementioned is the subject of this paper, the aim of which is to observe the adequacy of criminal law incriminations of organized crime, on the one hand, and the adequacy of criminal penalties imposed, on the other.

That is why we are talking about the legislator's penal policy and the penal policy of the courts when it comes to organized crime. The paper is a continuation of earlier researches of authors on this topic ${ }^{5}$, in which the

long-term imprisonment, it is quite justified to understand it as serious form of crime (Simović, Šikman, 2017, p. 206; Stojanović, Kolarić, 2014, p. 106).

${ }^{3}$ Thus, in one case, criminal groups confronted with each other, with several persons deprived of their lives using firearms and explosive materials (S1 2 K 00608714 Kžk of 22.05.2017), while in the other case more serious murders were done within one criminal group (S1 2 K 00608714 Kžk of 16.04.2015). These events had a great impact on the public, and they also received a court epilogue.

${ }^{4}$ One of the most notorious cases is the robbery of a money transport in 2010 in Dužice, near Široki Brijeg, when between 7 and 10 million KM were taken and the perpetrators have not been discovered to date (Vukić, 2010).

${ }^{5}$ The first part of the research was presented at the conference "Penal Policy and Crime Prevention", held in April 2019 in Trebinje, organized by the Serbian Association for Legal Theory and Practice. The paper entitled "Organized Crime - Criminology and Court Case Law in Bosnia and Herzegovina" was published in the Book of Papers from the conference (369-392). 
subject of research was criminal and court case law in criminal cases of organized crime in $\mathrm{BiH}$. As stated: ,taking into account the scope of work and limitations in this regard, the analysis of criminal sanctions for criminal offenses of organized crime is a subject of a separate paper, which will present more detailed results of research" (Šikman, 2019, p. 371). In support of the need for this type of research the authors point out that other researches in $\mathrm{BiH}^{6}$ have not been realized so $\mathrm{far}^{7}$, while research into related issues, such as corruption and terrorism ${ }^{8}$, has been carried out.

\section{PENAL POLICY IN RELATION TO ORGANIZED CRIME}

Although some of these issues are a matter of debate among lawyers ${ }^{9}$, penal policy ${ }^{10}$ in relation to organized crime is viewed as a policy of prescription pertaining to these criminal offenses and criminal sanctions (including other criminal justice institutions depending on the specificity of the criminal sanction in a particular criminal matter), as well as the policy pertaining to the imposition of criminal sanctions (compare Bejatović, 2019, p. 222). The first part of this approach should not be disputable, since the legislator implements the state's criminal-political orientation in relation to the fight against crime by prescribing criminal offenses and criminal

${ }^{6}$ Similar research has been done in Serbia (Fight against Organized Crime in Serbia Legislation and Practice, 2008) and Montenegro (Analysis of Judgments for Criminal Offenses with Organized Crime Elements: Prevention or Encouragement of Organized Crime).

${ }^{7}$ In 2014, the Center for Security Studies published the "Study on Organized Crime in Bosnia and Herzegovina" which aims to: "identify areas of real threats, from the civil society perspective, that should be taken into account when making strategic national strategies with recommendations for specific operational plans for the fight against organized crime" (Center for Security Studies, 2014, p. 6).

${ }^{8}$ One research was prepared by the Court of $\mathrm{BiH}$ in 2017, entitled "Prosecution of Corruption and Terrorism Cases before the Court of Bosnia and Herzegovina" (see: Court of $\mathrm{BiH}, 2017$ ), while the other that may be cited is USAID's Judiciary Project in Bosnia and Herzegovina within which in 2017 presented "Analysis of Prosecution of Criminal Offenses of Corruption in Bosnia and Herzegovina through a Case Study Selection" (see: USAID, 2017). Also, we can mention researches conducted by the OSCE Mission to BiH entitled "Assessing the Needs of the Judiciary in Prosecution of Corruption through Monitoring the Work on Criminal Cases", which published two assessments in 2018, "Monitoring the prosecution of corruption cases in $\mathrm{BiH}$ : first assessment" (see: OSCE Mission to $\mathrm{BiH}, 2018$ ) and 2019 "Monitoring the prosecution of corruption cases in $\mathrm{BiH}$ : second assessment (see: OSCE Mission to $\mathrm{BiH}, 2019$ ).

${ }^{9}$ The concept of penal policy is quite differentiated in the sense of criminal law science and can be regarded both in the widest sense as policy in general (Jakulin, 2012, p. 129), or in narrower either as penal policy of the legislation or as penal policy of the courts.

${ }^{10}$ The concept of penal policy in the science of criminal law is quite differentiated and can be observed from the broadest sense as a policy in general (Jakulin, 2012, p. 129) to narrower understandings, either as penal policy of the legislator or penal policy of the courts. 
sanctions ${ }^{11}$. The second part, although containing the word 'policy', is also not disputable because the courts, as well as other bodies of formal social control, make decisions within their jurisdictions that form part of the prosecution policy (Ignjatović, 2012, p. 103). In fact, it should be taken into account that the provisions of criminal law related to sentencing $(\mathrm{CC} \mathrm{BiH}$, Article 48) are, by their nature, such that they leave enough room for court sentencing (Risimović, Kolarić, 2016, p. 2). Due to the fact that there is a low degree of attachment to the law, that the law establishes only some general and very broad legal frameworks, it can be said that these frameworks enables the courts to conduct only certain penal policy (Stojanović, 2012, p. 8).

When it comes to the prescribing of criminal offenses of organized crime, this is one of the most complex issues because the very concept of organized crime ${ }^{12}$ is quite disputable and subject to discussions of different nature (scientific, practical, etc.) (Simović, Šikman, 2017, p. 210). The key question is how and in which way to incriminate the already wide range of behaviors that constitute organized crime, so that such a norm is adequate and consistent with the international legal framework in this field. Therefore, the general concept of organized crime, as stated by Škulić (2015): ,is not solely based on the norms of positive legislation, but rather refers to the defining of the entirety of this form of crime and basically explains those most typical ones, and also the most serious forms of organized crime actions, which means that it does not cover all criminal offenses committed by organized criminal groups as defined by our positive criminal legislation, nor by the members of such criminal group“ (p. 56).

In this sense, these criminal offenses are prescribed by all criminal laws in $\mathrm{BiH}^{13}$ (Criminal Code of $\mathrm{BiH}$, Criminal Code of the Federation of $\mathrm{BiH}^{14}$, Criminal Code of the Republika Srpska ${ }^{15}$ and Criminal Code of

\footnotetext{
${ }^{11}$ As these are the most serious crimes, there is no dispute about the necessity to prescribe these behaviors as criminal offenses. What can be discussed here is the way they are prescribed.

${ }^{12}$ Before all, organized crime is a concept of criminology nature, whilst, from the position of criminal and substantive law, it includes numerous different criminal offenses (Stojanović, Kolarić, 2014, p. 105, 106).

${ }^{13} \mathrm{In} \mathrm{BiH}$, when it comes to criminal law, there are four criminal laws that are established on the principles of parallel and divided jurisdiction, according to the constitutional order of $\mathrm{BiH}$. Thus, there are the Criminal Code of $\mathrm{BiH}$, the Criminal Code of the Federation of $\mathrm{BiH}$, the Criminal Code of the Republika Srpska and the Criminal Code of the Brčko District of $\mathrm{BiH}$.

${ }^{14}$ Chapter XXIX (Criminal Offenses Against Judiciary) of the Criminal Code of the Federation of $\mathrm{BiH}$ defines that these are the following offenses: Arrangement for Committing Criminal Offenses Article 338, Preparation of Criminal Offenses, Article 339, Association for the Purpose of Commission of Criminal Offenses, Article 340, Participation in Criminal Offense Group, Article 341, Criminal Organization, Article 342 (Criminal Code of FBiH, Official Gazette of FBiH, 2003, 2004, 2005, 2010, 2011, 2014, 2016).
} 
Brčko District of Bosnia and Herzegovina ${ }^{16}$ ). The legal basis for these incriminations are international law documents, but primarily, it is the United Nations Convention against Transnational Organized Crime (2000), adopted by the United Nations in 2000 (the so-called Palermo Convention), and its three additional Protocols ${ }^{17}$, and the Framework Decision of the European Union on the Fight against Organized Crime from 2008 (Council Framework Decision 2008/841/JHA) which incriminate criminal offenses related to the involvement in a criminal organization. Therefore, the concept of organized crime includes the joint commission of criminal offenses by members of criminal association, leaving the possibility to associate to commit a wide range of criminal offenses (Stojanović, Kolarić, 2014, p. 106). Thus, in a separate section of the $\mathrm{CC}$ of $\mathrm{BiH}$, the legislator devoted a chapter XXII Conspiring, Preparation, Association and Organized Crime - that prescribes criminal offenses of conspiring to commit criminal offenses (Article 247), the preparation of a criminal offense (Article 248), association for committing criminal offenses (Article 249) and organized crime (Article 250), which emphasizes a high degree of danger of these criminal offenses that justifies their incrimination (Бабић, М. ет ал., 2005, p. 794). By criminal offenses prescribed under this Chapter, criminal organizations aimed at the continuous commission of criminal offenses which have the characteristics of organized crime and which are provided for by the said Law, can be organized. It is noted that this Criminal Code contains a criminal offense called Organized crime (Article 250), which is not common ${ }^{18}$ since this offense understands the commission of any criminal offense prescribed under $\mathrm{BiH}$ law by a

${ }^{15}$ In Chapter XXVIII (Criminal Offenses against Public Order and Peace) of the Criminal Code of the Republika Srpska, these criminal offenses are systematized, and they include: Arrangement for the commission of criminal offense, Art. 364, Association for the Purpose of Committing of Criminal Offenses, Art. 365, Commission of a criminal offense within the criminal association, Art. 366, Participation in a Group that Commits Criminal Offense, Art. 367 (Criminal Code of the Republika Srpska, 2017, 2018).

${ }^{16}$ In the Criminal Code of Brčko District of $\mathrm{BiH}$, these are Criminal offenses against judiciary: Arrangement for the commission of criminal offenses, Art. 332, Crime preparation, Art. 333, Association for the purpose of committing of criminal offenses, Art. 334, Participation in a group that commits criminal offense, Art. 335, Criminal organization, Art. 336 (Criminal Code of Brčko District of BiH, 2013, 2016).

${ }^{17}$ These are the three protocols regulating transnational organized crime in specific areas: the Protocol to Prevent, Fight and Punish Trafficking in Human Beings, Especially Women and Children (2000), the Protocol against the Smuggling of Migrants by Land, Sea and Air (2000) and the Protocol against Illicit Production and Trade in Firearms, Their Parts and Ammunition (2003).

${ }^{18}$ Comparative criminal legislation avoids naming a criminal offense in this way, as Stojanović and Kolarić (2014) state: "such a provision would have to be extremely broad, to cover a large number of behaviors that could be included into that concept, which would be in direct opposition to the principle of legality and its segment of lex certa, which emphasizes that the criminal law must specify as precisely as possible a certain conducts constituting criminal offense and the punishment for it" (p. 106). 
person being a member of organized crime group ${ }^{19}$ (paragraph 1); a criminal offense for which the sentence of three years of imprisonment or more severe sentence may be prescribed (paragraph 2), as more serious form; organizing or otherwise managing an organized crime group (paragraph 3), as an even more serious form; or if a person becomes a member of an organized crime group (paragraph 4) which commits or attempts to committ a criminal offense prescribed under $\mathrm{BiH}$ law by joint action, unless a more severe sentence is prescribed for an individual offense (Simović, Šikman, 2017, p. 251).

Quite severe penalties are prescribed for the aforementioned criminal offense of organized crime. Thus, a sentence of imprisonment for at least three years is prescribed for a basic form of criminal offense, and at least five years for its more severe form; a sentence of imprisonment of at least ten years or long-term imprisonment for organizing or managing a group, while the prescribed sentence of imprisonment of at least one year is prescribed for an admission to an organized crime group. It is also prescribed that a member of an organized crime group, including the organizer who discloses the group, may be released without punishment $(\mathrm{CC} \mathrm{BiH}$, Article 250, paragraph 5). Therefore, the criminal law framework, viewed through the provisions of substantive criminal law $^{20}$, taking into account the aforementioned objections, can be considered as adequate. Criminal offenses by which a criminal group for organized crime may be formed, as well as appropriate penalties for such behaviors have been prescribed.

Case law in organized crime cases is about the application of legal provisions and decision-making in accordance with these provisions. When the legislator has adopted a system of relatively specific penalties, when penalties for criminal offenses for organized crime are prescribed for a wide range of behaviors, determining the penalty is of great importance $^{21}$. The determining of penalty can be within the scope of a

\footnotetext{
${ }^{19}$ Organized crime group is a group of three or more persons, existing at a certain period of time and acting by agreement with the aim of committing one or more criminal offenses for which a sentence of imprisonment of more than three years or more severe punishment may be imposed under the law, for a purpose of acquiring of material benefit $(\mathrm{CC} \mathrm{BiH}$, Article 1 paragraph 22). In addition to this term, there is a related term of organized group in the $\mathrm{CC} \mathrm{BiH}$, which is a group of people formed for direct commission of criminal offense, and which does not have to have formally defined roles of its members, continuity of membership, or a developed structure $(\mathrm{CC} \mathrm{BiH}$, Article 1, paragraph 21) to make a distinction in relation to organized crime group.

${ }^{20}$ The criminal law framework against organized crime also includes the provisions of criminal procedural legislation. Before all, they concern the introduction and application of special investigative actions in detecting and proving of these criminal offenses (see more in Simović, Šikman, 2017).

${ }^{21}$ In literature, when it comes to determining a penalty in general, it is widely accepted that only court's penalty is a penalty in the true sense of the word, while legal determination of penalty is in principle in abstracto (Stojanović, 2009, p. 268).
} 
penalty for a specific criminal offense, a penalty less aggravating than the prescribed penalty (penalty mitigation) or a penalty more aggravating than the prescribed penalty (sentence enhancement) (Stojanović, 2009, p. 268). However, case law cannot only be a mere decision-making process, since even this process involves the conscious involvement of judges, which includes interpretation and judgment, etc., but every court decision reveals the sociological situation and its relationship with the legal system (Rašović, 2017, p. 121). Thus, the case law should answer two questions on different sides. The first one concerns the equal and harmonized application of rights, which ensure the generality of the law, equality before the law and legal certainty ${ }^{22}$. The starting point is that the purpose of the court decision is not only to resolve the dispute in question by providing legal certainty to the parties, but often to establish case law that can prevent occurence of other disputes and provide social harmony (Consultative Council of European Judges (CCJE), 2008). The answer to the second question strives to understand that the court should adapt the penalty in each individual case to the perpetrator of the criminal offense because it is only in this manner that the purpose of punishment can be achieved (Risimović, Kolarić, 2016, p. 2). Regardless of the fact that the issue of individualization of penalty, i.e. determination of personalityoriented penalty, is justifiably criticized ${ }^{23}$, it still occupies an important place in the decision-making process of the courts.

Finally, the assessment of the adequacy of penal policy in cases of organized crime can be seen as a useful question. The term adequacy of criminal legislation and penal policy could be used as an answer to this question, and according to Bejatović (2018) this term implies: "the policy of prescribing criminal justice measures and other instruments for the necessary degree of state's opposition to criminal activities of any kind and for the policy of imposing criminal sanctions and application of other criminal measures against the perpetrators of criminal offenses" (p. 9). Thus, the general aim would be to enable the application of a substantive criminal law to a particular case, i.e. to determine by a court decision whether a criminal offense was committed, whether it was committed by the accused, whether a criminal sanction can be imposed on the accused

\footnotetext{
${ }^{22}$ Namely, according to Opinion no. 20 of the Consultative Council of European Judges (2017), in the country of the rule of law, each citizen reasonably expects to be treated like others, and to be able to rely on previous decisions in comparable cases and thus foresee the legal consequences of his actions or omissions (Consultative Council of European Judges (CCJE), 2017, pp. 5 and 6).

${ }^{23}$ As Stojanovic (2009) notes: "not only that orientation to treatment and re-socialization as a pillar of the criminal law have been abandoned, but also determination of personalityoriented penalty is an illusion leading to an enormously wide scope of free choice to decide when determining the penalty, and thus to arbitrariness and even abuse" (p. 268).
} 
(Simović, Simović, 2016, p. 35), while the specific aims concern the individual phases and stages of the procedure, which fit into the general objective (Simović, Simović, 2016, p. 35). In this sense, a quality court decision and impartial consideration of all issues (factual and legal) are integral parts of such perceived efficiency (Fillipović, 2017, p. 6). Of course, it is understood that this decision was reached in the optimal time period, i.e. the time that was objectively necessary to resolve the criminal case without undue delay, with full respect for the lawfulness of its conduct (Bejatović, 2015, p. 28).

\section{METHODOLOGY APPLIED IN THE PAPER}

In order to determine the adequacy of penal policy in organized crime cases, an analysis of the content of court judgments in these cases was made. The data was collected from court decisions in selected organized cases of organized crime in the period between 2015 and 2018 that were conducted before the Court of $\mathrm{BiH}$. The data was collected through the web page of the Court of $\mathrm{BiH}^{24}$, by selecting in the section Case law of $\mathrm{BiH}$ year: 2018, 2017, 2016, 2015, Section: Section II, Type of judgment: the first instance judgment. By selecting the appropriate parameters, one can find necessary information, including: information on the accused, information on the case (indictment, course of the case, etc.), press releases related to the case, as well as the Court documentation, i.e. judgments, rulings, decisions and others. For the analysis in question, the authors selected criminal offenses which are typical for the activities of organized crime groups. The analysis included 21 judgments convicting 44 persons according to the following types of criminal offenses: organized crime in relation to the criminal offense of illicit trafficking of narcotics - 6 judgments; organized crime related to the criminal offense of human trafficking - 4 judgments, two of which referred to cases where the indictment was altered to criminal offense of international incitement to prostitution; organized crime related to criminal offense of robbery, murder and other crimes - 4 judgments; organized crime related to document forgery - 3 judgments; and one judgment for each criminal offense of organized crime related to: illicit trafficking of arms, military equipment and dual-use products; criminal offense of organized crime in relation to tax evasion or fraud; and the criminal offense of organized crime in relation to abuse of position and smuggling (compare: Šikman, 2019).

After collecting the data, their systematic, accurate and objective analysis was started by using the methods of analysis (of content) of the documents $^{25}$. In this sense, both qualitative analysis (extraction of specific

\footnotetext{
${ }^{24}$ According to: Court of Bosnia and Herzegovina, web page: http://www.sudbih.gov.ba/

25 According to the results of methodological researches and theoretical-empirical analyzes, according to Milan Miljević (2007), it follows that "document analysis is an
} 
observations) and quantitative content analysis ${ }^{26}$ (numerical presentation of analyzed contents) were applied. Thus, the analysis identified and analyzed the following categories ${ }^{27}$ : the type and duration of imposed criminal sanction for criminal offense of organized crime, general rules for determining the penalty (aggravating and mitigating circumstances), and the use of plea agreements as a separate institute of simplified form of actions in criminal proceedings. Of course, this research recognizes its shortcomings and they are primarily related to the sample. Therefore, these results can be used to draw partial conclusions, which need to be brought into connection with other aspects of the problem.

\section{SURVEY OF RESEARCH RESULTS WITH DISCUSSION}

The results of the survey are presented in three categories: the first, type and amount of imposed penalty for criminal offenses of organized crime; the second, the general rules for determining the penalty (aggravating and mitigating circumstances), and the third, the use of plea agreement.

\section{The Type and Amount of Criminal Sanction}

The analyzed decisions of the Court of Bosnia and Herzegovina impose penalties, warning measures and security measures on the accused persons.

Among penalties, the most frequent was the sentence of imprisonment, which was pronounced in $85.71 \%$ of cases, while $14.28 \%$ of cases were concluded with probation ${ }^{28}$. In one case, long-term imprisonment was imposed, and in the other, a maximum term of 20 years of imprisonment. Thus, in one of the most important criminal proceedings in cases of organized crime, conducted from 2010 to 2015, which included a

irreplaceable, pervasive and reliable operational method of collecting and treating data on past, present and future phenomena, on territorially and temporally close but also very distant occurrences. A direct object of research through the analysis of documents can be any factor, part or whole phenomenon, its quantitative or qualitative characteristic, etc., if it is in any way recorded" (p. 235).

${ }^{26}$ Using both approaches in the same research is a way to overcome the shortcomings of quantitative and qualitative content analysis individually, that is, to take advantage of the application of both of them, which enables to obtain better results (Manić, 2014, p. 56).

${ }^{27}$ Here, we emphasize that, due to the incomplete content of the available data, these categories were not precisely defined in advance, but were established on the basis of the experiential material itself (compare: Manić, 2014, p. 50).

${ }^{28}$ With a suspended sentence, the court determines the sentence to the perpetrator of the criminal offense and at the same time determines that it will not be executed if the convicted person does not commit a new criminal offense during the period determined by the court, which cannot be less than one year or more than five years (probation time) (CCBiH, Article 59 paragraph 1). 
criminal organization ${ }^{29}$ characterized by extreme cruelty, brutality and malice in its actions ${ }^{30}$, the organizer and one member of the group were sentenced to long-term imprisonment (40 and 35 years), and others to sentences of imprisonment (Judgment of the Court of BiH, Case No. S1 2 K 00608714 Kžk of 16 April 2015 [1S1 2 K 00608714 Kžk of 16 April 2015]). In another case, conducted from 2013 to 2016 against 32 persons accused of being members of one of the largest organized crime groups ${ }^{31}$, not only in $\mathrm{BiH}$, but also in the region, were charged with organized crime in relation to multiple killings and aggravated murders, robberies (of banks and multi-million dollar money transports), money laundering and other serious criminal offenses, and adequately sentenced to imprisonment, including one for a maximum term of 20 years (S1 2 K $01538414 \mathrm{~K}$ of 14 September 2016). In the same criminal case, the Appellate Panel's decision upheld the appeal by the Prosecutor's Office of $\mathrm{BiH}$ and altered the first instance judgment in terms of the sentence, increasing the sentence of imprisonment from 13 to 15 years (S1 2 K $01375615 \mathrm{Kž} 3$ of 10 March 2016), and this can be cited as an example of adequacy.

In addition to that, in the second case of organized crime in relation to the criminal offense of illicit drug trafficking, the court pronounced sentences of imprisonment in term of five and seven years, respectively (S1 $2 \mathrm{~K}$ $01790115 \mathrm{~K}$ of 05 May 2017). Similarly, in the third criminal case, in addition to the sentence of imprisonment (in this case, six years of imprisonment), the second defendant was fined as secondary penalty (in the amount of KM 50,000), and the property gained was seized from both defendants (S 12 K $02063216 \mathrm{~K}$ dated 16 June 2017). On the other hand, there may be cases where penalties are imposed at the lower minimum of the

\footnotetext{
${ }^{29}$ The aforementioned organized crime group operated from the beginning of 2005 to September 2010, and was aimed at the illicit drug trafficking (heroin and cocaine). Also, this group by its joint actions organized, committed a criminal offense of aggravated murder (in a cruel and treacherous manner), attempted murder, and the caused a general threat to life and property of greater scope with an explosion (S1 2 K 00608714 Kžk of 16 April 2015).

${ }^{30}$ Namely, as it follows for presented evidence, murders in question were committed by fraud in term of accessing the victim, since murdered persons were not able to notice actions before the murder, did not expect it and could not provide any resistance. The accused persons relied on trust between murdered persons on the one hand, and the accused on the other, since it was a long term acquaintance and persons worked together (S1 2 K $00608711 \mathrm{~K}$ of 29 November 2013).

${ }^{31}$ Indictment of the Prosecutor's Office of BiH No. T20 0 KT 00265412 of 28 August 2013; which was upheld by the Court of $\mathrm{BiH}$ on 04 September 2013, initiated the criminal proceedings in the case under number S1 2 K 01375613 Ko. On 9 May 2014 the main trial was initiated before this Court against the aforementioned accused persons, which was concluded on 14 September 2016 by the first instance judgment, that is on 22 May 2017 when the second instance judgment was passed (S1 2 K $01538414 \mathrm{~K}$ of 14 September 2016 and S1 2 K 00608714 Kžk of 22 May 2017).
} 
sentence prescribed for the criminal offense. Although the Court moved within the limits prescribed by law, in some cases it was evident that only mitigating circumstances (e.g. confessing to a crime and proper attitude before the Court) were taken into account, but not the aggravating circumstances, although, for example, in the reasoning of the particular judgment it is stated that the accused took advantage of the victims' difficult financial situation (S 12 K $01479214 \mathrm{~K}$ of 7 March 2017). However, we may consider it is correct standing to take as mitigating circumstances the fact that the accused was prepared to testify against the organized crime group whose member he was (S1 2 K 02615517 K of 11. September 2017; S1 2 K 02445917 K of 28 February 2017; S1 2 K 02606417 K of 24 August 2017), which is certainly in accordance to the criminal-political orientation to impose less severe sentences on those members of the group willing to contribute to criminal proceedings in this way ${ }^{32}$. These criminal sanctions may be considered adequate given that they are imposed within the limits of the penalties prescribed for a specific criminal offense.

Furthermore, in certain cases, penalties were imposed below the prescribed minimum. Namely, in some cases of organized crime, mitigation of the sanction prescribed under the law was also recorded (see Articles 49 and 50 of the $\mathrm{CC} \mathrm{BiH}$ ), which raises the question of adequacy of punishment for such serious criminal offenses ${ }^{33}$. Even the fact that the accused did not obtain personal gain from criminal acts committed, but acted for the organizers of the group (S1 2 K 02668417 Ko of 20 November 2017) or expressed his willingness to repay the amount of illicitly obtained property gain (S1 $2 \mathrm{~K} 02516817 \mathrm{Ko}$ of 12 May 2017), that is, the existence of other particularly mitigating circumstances, raises the question of whether reaching the purpose of punishment is possible by mitigating the punishment. Especially considering that in the other case the same Court allowed as mitigating circumstance the statement that the accused acted

\footnotetext{
${ }^{32}$ In this case, it is a kind of procedural "hybrid", that is, an entity in which procedural characteristics of the accused and the witness are "mixed" (Škulić, 2015, p. 406). According to Škulić (2015), ratio legis of enabling of such procedural transformation (accused into witness) is based on two basic assumptions: "on one hand, on the awareness that without persons who were actively involved in the activities of certain criminal organizations (the so-called insiders) it is practically almost impossible to obtain necessary evidential information, and on the other hand, on noting that it is better for a society to have a number of less dangerous perpetrators of criminal offenses, who were not dominant generators of criminal activities of a particular organization, consciously does not cover criminal justice repression but, under necessary conditions, that they have crucially contributed to the success in proving, by their cooperation in criminal proceedings against much more dangerous perpetrators of criminal offenses," (p. 408).

${ }^{33}$ In one criminal case, the total illegal property gain was determined in the amount of KM 348,902.00, which can be considered as qualified circumstance (S1 2 K 026684 17 Ko of 20 November 2017).
} 
only on the request of his brother, which in no case could exclude or diminish criminal liability of the accused (S $12 \mathrm{~K} 02063216 \mathrm{~K}$ of 16 June 2017). Moreover, in some cases the Court found the existence of aggravating circumstances (e.g. S1 2 K 02310916 K of 10 March 2017 and other judgments), but did not regard them as a decisive fact to mitigate the sentence. We need to emphasize on the fact that the Court mitigated the penalties for criminal offenses of organized crime related to narcotics $^{34}$ (S1 2 K $01933215 \mathrm{~K}$ of 27 August 2015), robberies ${ }^{35}$ (S1 2 K $02129216 \mathrm{~K}$ of 04 April 2016), abuse of office ${ }^{36}$ (S1 2 K 02361716 Ko of 08 November 2016), etc., and this gives sufficient reason for concern. The position of the Court in other criminal cases should also be added to the aforementioned, and that is that: ,aggravating circumstance may be considered to be commission of criminal offenses as part of an organized crime group, given that organized crime is the most dangerous form of crime today" (S 12 K $02063216 \mathrm{~K}$ of 16 June 2017). However, a differentiation should also be made regarding the amount of mitigated sentence, as in some cases severe sentences of imprisonment were imposed, even when they were mitigated, e.g. more than five years of imprisonment (S1 $2 \mathrm{~K} 01937315 \mathrm{~K}$ of 10 January 2017), while in other cases penalties were maximally mitigated (S1 2 K $02129216 \mathrm{~K}$ of 04 April 2016).

We also feel obligated to mention such cases where probation for criminal offenses of organized crime was granted (S1 2 K $02762418 \mathrm{~K}$ of 25 January 2018; S1 2 K 02566617 K of 10 July 2017; S1 2 K 02140116 K of 11 April 2016). The question arises as to whether sending a warning with the threat of punishment can achieve the purpose of punishment in cases of serious criminal offenses such as organized crime. If the accused discloses the organized crime group, as well as the organizer, the structure, positions and roles of the members (S1 $2 \mathrm{~K} 02566617 \mathrm{~K}$ of 10 July 2017), for which he may be released from punishment according to the Criminal Code of $\mathrm{BiH}$ (Article 250 paragraph 5), then the imposition of a suspended sentence is justified. On the other hand, by taking the contradictory position that the accused ,played a minor role, but which was essential for the commission of the crime" (S1 $2 \mathrm{~K} 02762418 \mathrm{~K}$ of 25 January 2018), and taking into account other mitigating circumstances (the frivolity of the accused, age, difficult financial situation, family circumstances), with the striking absence

\footnotetext{
${ }^{34}$ Especially when it comes to the protective good, which is the health of the people, as well as subjective element of the perpetrator, which is the desire and awareness of participation in the said criminal offenses.

${ }^{35}$ Especially when taking into account the manner in which this criminal offense was committed, the use of firearms, the threat to the life and limb of the injured parties (S1 2 K 02129216 K of 04 April 2016).

${ }^{36}$ In this case, a property gain in the amount of $\mathrm{KM} \mathrm{50,000} \mathrm{was} \mathrm{obtained,} \mathrm{which} \mathrm{is}$ considered to be a serious criminal offense (S1 2 K 02361716 Ko of 08 November 2016).
} 
of aggravating circumstances in specific criminal cases, brings into question the achievement of purpose of criminal sanctions in such a way as to influence the accused not to commit criminal offenses in the future (special prevention), and to prevent others from committing criminal offenses (general prevention).

In addition to the penalties, in the analyzed court cases, the accused persons were also ordered security measures, which were intended to remedy the state or condition that may have impact on the perpetrator to commit criminal offenses in the future $(\mathrm{CC} \mathrm{BiH}$, Article 68$)$. Thus, in 13 cases or $61.9 \%$ of cases, a security measure of confiscation of objects was pronounced, and in one case a ban on calls, activities or duties (S1 $2 \mathrm{~K}$ 02668417 Ko of 20 November 2017). Namely, the CC of BiH in Article 74 prescribes that objects which, in any way, in whole or in part, were used or intended to be used for the commission of the criminal offense or which were created by the commission of the criminal offense shall be confiscated if they are the property of the perpetrator (paragraph 1), or shall also be confiscated if they are not the property of the perpetrator, but if this does not affect the rights of third parties to compensate damage from the perpetrators (paragraph 2 ). Various items are confiscated, mostly passenger vehicles, mobile phones with their SIM card, narcotic drugs, but also immovable property ${ }^{37}$, and other items used in the commission of the criminal offense ${ }^{38}$.

Finally, although not a criminal sanction but a sui generis measure (Stojanović, 2009, p. 315), in a certain number of analyzed cases where a court decision established the commission of a criminal offense property gained in the commission of the offense was confiscated. The basis for its application is in the principle that no one can retain the property gain, income, profit or other gain obtained by criminal offense $(\mathrm{CC} \mathrm{BiH}$, Article 110 ), therefore, ratio legis of this provision is to prevent persons from "enjoying the results" of the criminal offense. Thus, in one case the defendant's property gain obtained by criminal offense in the amount of EUR 7,100.00 (seven thousand one hundred) was confiscated (S1 2 K 01937315 K of 10 January 2017), in the other EUR 85,000.00 (eighty-five thousand) (S $12 \mathrm{~K} 02063216 \mathrm{~K}$ of 16 June 2017), while in the third, the right of ownership (of real estate and company) was taken away (S1 2 K 00608711 $\mathrm{K}$ of 28 November 2013), as well as smaller amounts in other cases.

\footnotetext{
${ }^{37}$ In one case, a garage of $18.68 \mathrm{~m} 2$ (S $12 \mathrm{~K} 02063216 \mathrm{~K}$ of 16 June 2017) was seized from the accused.

${ }^{38}$ For example, a VF transmitter - GSM signal jammer was confiscated in one proceedings (C1 2 K 00608711 K of 28 November 2013.).
} 


\section{General Rules for Determining the Penalty}

Determining of penalty is a very important part of criminal law (Babić, Marković 2008, p. 162) because its correct application achieves the purpose of punishment and, consequently, the penal policy. As the basic criterion for the determining of penalty is the limit of the prescribed penalty, its achievement of the purpose of punishment is not disputable, because it is determined by the law as such. In this sense, the penalty imposed by the court in the regular determination of penalty must range between the specific minimum and the specific maximum. The important criteria are the aggravating and mitigating circumstances, which serve to reach a specific penalty within prescribed ones, taking into account the purpose of the penalty (Stojanović, 2009, p. 271).

In relation to circumstances prescribed under the law that are taken into account when determining the penalty (the degree of guilt, the motive for commission of the offense, the severity of the threat to or violation of protected good, circumstances under which the criminal offense was committed, earlier life of the perpetrator, his personal circumstances and his attitude after commission of the criminal offense, as well as other circumstances pertaining to the perpetrator's personality) (CC BiH, Article 48 paragraph 1), it is evident in the analyzed court decisions that the Court took into account only certain aforementioned categories. That is, what was taken into consideration and regarded as mitigating circumstances were the attitude of the offender after the commission of the criminal offense, and in particular, the admission of guilt for the crime in question, the expression of sincere remorse, the readiness of the accused to return property gain obtained by criminal offense, the correct attitude before the Court. In some cases, the Court assessed the accused's promised cooperation with the Prosecution as particularly mitigating circumstances in terms of the accused agreeing to testify against other defendants from the specific Indictment and to present everything he knew about the criminal offense, which could contribute to the more economic and efficient criminal proceedings (S1 $2 \mathrm{~K}$ $01933215 \mathrm{~K}$ of 27 August 2015; S1 2 K $02445917 \mathrm{~K}$ of 28 February 2017; S1 2 K 02129216 K of 04 April 2016). Also, in one case, the Court regarded as aggravating the fact that the accused had been on the run for a relatively long period of time (S $12 \mathrm{~K} 02063216 \mathrm{~K}$ of 16 June 2017). On the side of personal circumstances, in many cases the Court established family circumstances ${ }^{39}$, such as poor financial situation, poor health condition which is regarded as a mitigating circumstance. It is interesting

\footnotetext{
${ }^{39}$ In one case the Court took into account the fact that the accused: "has his family to which he wishes to contribute maximally after serving the sentence" (C1 2 K $02606417 \mathrm{~K}$ of 24 August 2017.), while in other case: "it is a younger age person, living together with his mother and sick sister" (C1 2 K 02310916 K of 10 March 2017.).
} 
that the Court did not consider these circumstances in another context, as for example in one case where the Court, as mitigating circumstances of the accused, assessed the fact that he was ,the father of two children“ (S1 $2 \mathrm{~K}$ $01790115 \mathrm{~K}$ of 05 May 2017) and in the other one that the accused were „family people“ (S1 2 K 02354517 Ko of 30 November 2017), without taking into account the fact that in both cases the father and the son/s participated together in the execution of criminal offense and were sentenced to imprisonment by the same judgment.

Interesting are also the findings of the Court in relation to the previous life of perpetrators, when criminal history of the perpetrator is concerned. Thus, not having prior convictions was taken as mitigating circumstance, while the fact that the accused had previously been convicted was usually treated as aggravating. However, in some cases the Court did not consider earlier conviction as an aggravating circumstance, since it was not a conviction for the same or similar offense (S1 2 K $02310916 \mathrm{~K}$ of 10 March 2017) or even if it was a criminal offense „twice the same criminal offense", the Court took into account that this was not a decisive fact (S1 2 $\mathrm{K} 02310916 \mathrm{~K}$ of 10 March 2017) or that a significant period of time had passed since previous convictions (S1 2 K 02606417 K of 24 August 2017; S1 2 K 02445917 K of 28 February 2017).

On the other hand, there have been a few cases where the Court considered the circumstances affecting the determination of the degree of guilt, the motives for which the offense was committed, the severity of the threat or violation of protected good and the circumstances under which the offense was committed. It is clear that these circumstances in organized crime cases are aggravating circumstances, since the intent of the perpetrator to commit the said criminal offenses, the manner and means of its commission, the consequences of these criminal offenses, indicates precisely that $^{40}$. Thus, the degree of guilt, which is reflected in: „long, systematic planning of individual killings, cruelty of killings, with consequences that are extremely serious and the number of persons killed and committed criminal offenses", persistence in commission of criminal offenses, the severity of violation of protected good, that is, the consequences of criminal offenses, which are reflected in one case in the death of five persons and one unborn child, expressed cruelty in the commission of murder (in the specific case it was established that killed persons got "signature headshot") (S1 2 K 006087 $11 \mathrm{~K}$ of 28 November 2013), were taken as aggravating circumstances.

Also, the fact that: ,the accused have shown particular persistence, especially when one appreciates the time continuity and organization of

\footnotetext{
${ }^{40}$ It is therefore surprising to see the Court's position in some cases that: "in determining the penalty to the accused the Court found no elements which could be characterized as aggravating circumstances" (S 12 K 01479214 K of 07 March 2017; S 12 K 02383816 K of 29 December 2016, S1 2 K 02516817 Ko of 12 May 2017).
} 
activities in this group, all related to the intensity of the desire of the accused persons and harmful consequences, as well as the role the accused persons had in the said group and the chain of execution of prepared actions" was regarded as an aggravating circumstance (S $12 \mathrm{~K} 02063216 \mathrm{~K}$ of 16 June 2017). Furthermore, as aggravating circumstances in the particular case, the Court assessed: "first of all, the position held by the accused at the time of commission of the offense, that is, that during the whole period he was a high-ranking police officer and that he committed certain criminal offenses by using his official position" (S1 2 K $01538414 \mathrm{~K}$ of 14 September 2016). Similarly, the accused's family circumstances (father of an underage child) were not considered by the Court as mitigating circumstances in the particular case because the specific nature of the committed crime did not have the greater good in mind, included an utter disregard for human health and there certainly had to exist a will and awareness for the participation or commission of such criminal offense. (S 1 $2 \mathrm{~K} 02063216 \mathrm{~K}$ of 16 June 2017). However, the fact that the accused took advantage of the victim's bad financial situation ${ }^{41}$ (S 12 K $01479214 \mathrm{~K}$ of 7 March 2017) was not considered as aggravating circumstance, and neither was the manner in which the criminal offense was committed, which was reflected in the use of firearms, a threat to the life and limb of the injured persons (S1 2 K 02129216 K of 04 April 2016).

It follows from the aforementioned that in the analyzed court judgments the Court in several cases reduced the penalties below the legally prescribed minimum, using this immediate basis for determining the penalty. It is evident that in these cases the circumstances having the character of mitigating circumstances were taken into account, while the aggravating circumstances were not considered decisive in the specific criminal cases. The stated cannot be completely justified considering the fact that persons charged with these criminal offenses of organized crime had motive for criminal offense, and awareness of the severity of the violation or the endangering of protected goods, as well as other facts that ascertain the character of aggravating circumstances.

\footnotetext{
${ }^{41}$ Thus, the reasoning of the judgment states: "As it appears from the statements of the injured parties, in the majority of cases, they were women from the territory of the Republic of Serbia, who were affected by the difficult material situation to agree to an offer to come to Bosnia and Herzegovina, i.e. Busovača. In their statements, the victims described in detail the manner in which they consented to provide sexual services, they cited the persons who explained them what their engagement was, and described all persons who participated in any way in their arrival, their consent to work at the facility “AS", and their stay at the said facility" (S 12 K 01479214 K of 07 March 2017).
} 


\section{The Guilty Plea Agreement}

The guilty plea agreement ${ }^{42}$ is an institute that has had its full application in criminal cases of organized crime. In the analyzed court proceedings, it is evident that the largest number of cases, $76.19 \%$ of them, were concluded through a guilty plea agreement. This has affected the efficiency and cost-effectiveness of specific criminal proceedings. Thus, for a better view, from the moment the indictment was confirmed (06 January 2015 ) to the guilty plea agreement in one criminal case, about six months (15 June 2015) have elapsed, while the proceedings for the other accused have been completed within more than three years (13 April 2018) (S1 $2 \mathrm{~K}$ 01790117 Kžk of 13 April 2018). In the second criminal case, two days have elapsed between the moment of the confirmation of the indictment and the first instance judgment (S1 2 K 02516817 Ko of 12 May 2017) (Šikman, 2019).

What is characteristic about this type of the proceedings, in these cases, is that they involved several members of an organized crime group. The proceedings are usually separate from those of the accused ones for whom the court has accepted a guilty plea agreement, while for the others criminal proceedings are conducted ${ }^{43}$ in a regular manner. However, it is clear that the main motive of the accused for entering into a plea agreement is the duration of the sentence, which usually goes below the statutory minimum. Thus, in many of the cases analyzed, the Court applied the provisions of Art. 39, 42 and 48 of the $\mathrm{CC}$ of $\mathrm{BiH}$, and by applying the rules on mitigation of sentence from Art. 49 and Art. 50th c. 1. t. b) The BiH Criminal Code, for the criminal offense in question, imposed penalties below the statutory minimum (Simović, Šikman, 2018). In these proceedings, the Prosecution uses the possibility to propose the imposition of a sentence below the legally prescribed minimum of sentence of imprisonment for that criminal offense, that is, a lighter sanction for a suspect or accused in accordance with the criminal law, which the Court accepts in most cases, citing particularly mitigating circumstances and the position that the sentence imposed is proportional with the gravity of the offense and the degree of guilt of the accused, while aggravating circumstances are not found or, in more flagrant cases, they are assessed as irrelevant. The „sufficient evidence“

\footnotetext{
${ }^{42}$ The suspect, i.e. the accused and his defense attorney, before the conclusion of the main hearing, i.e. hearing before the Appellate Panel, may negotiate with the prosecutor on the conditions for guilty plea for the offense for which the suspect, i.e. the accused is charged with (Criminal Procedure Code of $\mathrm{BiH}$ 2003, 2004, 2005, 2006, 2007, 58/2008, 2009, 2013 and 2018, Article 321 paragraph 1).

${ }^{43}$ For example, in one criminal case, nine out of 12 defendants, including the group organizer, entered into plea agreements with the Prosecution, which were subsequently confirmed by the Court. One person was unavailable to the Court and the other two were convicted in the proceedings (S1 2 K $02606417 \mathrm{~K}$ of 24 August 2017).
} 
standard, which the legislator prescribes as a requirement for accepting the agreement, was determined by the Court in analyzed cases on the basis of the confession of the accused and the evidence listed in the indictment in question to which the defense had no objection.

Therefore, a balanced position should be taken between the efficiency of criminal proceedings (primarily in terms of its duration) and the imposed penalties, because the imposed penalty below minimum prescribed for serious crimes under the law, which organized crime is, is certainly not the most adequate solution in terms of general or special prevention, and certainly not in terms of the achieving of the purpose of punishment. Also, the analyzed judgments show that sufficient evidence was gathered on the basis of which the Court could form an adequate decision, with great certainty, in the regular course of the proceedings. This is also supported by the fact that these are professional perpetrators of criminal offenses, often convicted of the same criminal offenses in the past ${ }^{44}$.

\section{CONCLUSION}

Based on the analysis of the legal framework and chosen court decisions, certain conclusions can be drawn regarding the adequacy of criminal policy in criminal cases of organized crime in $\mathrm{BiH}$. The first part deals with the criminal policy of the legislator, which is reflected in the prescribing of criminal offenses of organized crime. Although some solutions are not fully harmonized with international legal acts (for example, the prescribed minimum penalty for these criminal offenses), it may be considered that the legal framework against organized crime is adequate. In support of this, organized crime group was defined, and a clear distinction was made in relation to the organized group. Taking into account the objections to its name, the criminal offense of organized crime has been introduced into $\mathrm{CCBiH}$ in 2003 , including all the essential elements of incrimination of such behaviors (commission of criminal offense within the organized crime group, organizing or managing such a group, joining the group, as well as the possibility of a less severe punishment for those perpetrators who contribute to the detection and proving of these criminal offenses by their testimony).

The second part of the answer to the question about the adequacy of penal policy in criminal cases of organized crime was observed through

\footnotetext{
${ }^{44}$ In one case, during the course of criminal proceedings, while the accused was waiting for scheduled hearing, which considered his guilty plea agreement, he was, meanwhile, deprived of liberty by another prosecution for the same criminal offense. Although the Prosecution had the information in its possession, it did not abandon the proposed agreement and the Court accepted it despite the stated facts and he was determined a penalty below minimum prescribed under the law (Faktor.ba, 2015).
} 
case law. Therefore, when it comes to the imposed criminal sanctions for criminal offenses pertaining to organized crime, on the basis of the analysis of court judgments in these criminal cases, we can conclude that the judicial outcomes vary (Šikman, 2019). Although we have taken into account the individualization of criminal sanction and the purpose of punishment, there is still a discrepancy in criminal policy of the Court since even the same criminal offenses show quite different criminal sanctions. On the one hand, the most severe criminal sanctions were imposed and these were sentences of long term imprisonment (up to 40 years), as well as sentences of imprisonment in maximum duration (20 years). In certain cases, more severe sentences of imprisonment in the second instance ( 15 instead of 13 years of imprisonment) were imposed, as well as fines as ancillary sentences.

On the other hand, relatively mild sentences of imprisonment have been imposed in most cases, very often mitigated below the legal minimum, including suspended sentences and even acquittals (Šikman, 2019). In the analyzed court decisions, when it comes to determination of penalty, it seems that the Court does not pay sufficient importance to the determining of aggravating circumstances on the part of the accused persons, while, at the same time, overestimates the mitigating circumstances (for example, personal circumstances of the perpetrator or behavior after the crime was committed). The very fact that these are serious criminal offenses, which, among other things, are expressed through persistence and perseverance in criminal activity, indicates that aggravating circumstances are not adequately assessed. This affects the fact that the penalty imposed on the accused is not sufficiently proportional to the gravity of the criminal offense, especially when having in mind the manner of commission of criminal offense, the amount of material gain obtained, and the harm caused to the injured parties. Finally, it should be noted that, in addition to the imposed penalties, the accused persons were also ordered security measures of confiscation of items and prohibition to perform calls, activities and duties, as well as the confiscation of property gain obtained by criminal offense, as well as an obligation of convicted persons to jointly compensate the injured party in the determined monetary amount. On the part of the guilty plea agreement and the conclusion of criminal proceedings in this way, we can conclude that this institute had its full application. Although the justification for acting in this way is indisputable (the efficiency and cost-effectiveness of criminal proceedings), it should be taken in account that the motives of the parties to the agreement are clear: on the side of the accused it is sentence reduction, and on the side of the Prosecution it is the conclusion of the criminal matter. The above stated is certainly legitimate, but is not criminally justified in all cases, given the purpose of punishment for these criminal offenses.

If the two answers to the raised question about the adequacy of penal policy in criminal cases of organized crime are linked, then it can be concluded that it is not fully harmonized. There is a clear discrepancy 
between penal policies of the legislator and the Court on this issue. Although the legislator has set a relatively "harsh" penal policy on organized crime, it does not have its full application in the case law, which, on the other hand, is reflected in relatively "mild" penalties for the perpetrators of these criminal offenses. Therefore, it is necessary to move in two directions: the first, the harmonization of court case law with penal policy of the legislator, and the second, setting more realistic expectations by the legislator when incriminating these behaviors, taking into account both the court case law and the need for the harmonization of criminal legislation. The first part of this proposal can be achieved by more accurate determining of penalties by taking into account all the circumstances under which the criminal offense was committed, including the aggravating circumstances. Also, it would be important to take a clear standing as to what is to be considered as organized crime, since it is evident from the analyzed cases that all of stated behaviors did not have the elements of this criminal offense. The second part of the proposal refers to the legislator, who should certainly take into account the current court case law and consider the possibility to prescribe behavior, which is considered to be organized crime, even more precisely, for which it should certainly maintain a strict penal policy.

\section{REFERENCES}

Бабић, М., Марковић, И. (2008). Кривично право: општи дио [Criminal Law: General Part]. Бања Лука: Правни факултет Универзитета у Бањој Луци.

Бабић, М. ет ал. (2005). Коментари кривичних/казнених закона у Босни и Хериеговини [Comments to the Criminal Laws in Bosnia and Herzegovina]. Сарајево: Савјет/Вијеће Европе и Европска комисија.

Бејатовић, С. (2012). Кривичнопроцесни инструмени адекватности казнене политике [Criminal Procedure Instruments of Penal Policy Adequacy]. У: Бејатовић, С. ет ал. (ур.): Казнена политика (раскол између закона и његове примјене) [Pеnal Policy (Disruption Between the Law and Its Application)] (23-44). Источно Сарајево: Српско удружење за кривичноправну теорију и праксу.

Бејатовић, С. (2015). Ефикасност кривичног поступка као међународни правни стандард и реформа кривичног процесног законодавства Србије (норма и пракса) [Efficiency of Criminal Proceedings as International Legal Standard and Reform of Criminal Procedural Legislation of Serbia (Norm and Case Law)]. НБП - Журнал за криминалистику и право, 20(2), 27-53.

Бејатовић, С. (2018). Кривично законодавство и функционисање правне државе [Criminal Legislation and Functionning of Legal State]. У: Симовић, М. Н. (главни и одговорни уредник): Кривично законодавство и функиионисање правне државе, зборник радова, Trebinje 20-21. aprila 2018. godine [Criminal Legislation and Functioning of Legal State, Book of Papers, Trebinje, 20-21 April 2018] (231-241). Београд: Српско удружење за кривичноправну теорију и праксу [etc.].

Бејатовић, С. (2019). Казнена политка и превенција криминалитета [Penal Policy and Prevention of Crime]. У: Бејатовић, С. и Симовић, М. (ур.): Казнена политика и превениија криминалитета [Penal Policy and Prevention of Crime] (221238). Требиње: Српско удружење за кривичноправну теорију и праксу. 
Vukić, U. (5. 1. 2010). Ukrali oko pet miliona evra UniCredit banke. Nezavisne novine 5.1 .2010. Доступно на: https://www.nezavisne.com/novosti/hronika/Ukrali-oko-petmiliona-evra-UniCredit-banke/69680, приступљено 24. 8. 2019.

Закон о кривичном поступку БиХ, 3 (2003), 32 (2003) - испр., 36 (2003), 26 (2004), 63 (2004), 13 (2005), 48 (2005), 46 (2006), 29 (2007), 53 (2007), 58 (2008), 12 (2009), 16 (2009), 53 (2009) - др. закон, 93 (2009), 72 (2013) и 65 (2018).

Игњатовић, Ђ. (2012). Да ли је казнена политика судова у Србији одговрајућа? [Is Penal Policy in Serbia Appropriate?]. У: Бејатовић, C. et al. (ур): Казнена политика (раскол између закона и његове примјене) [Penal Policy (Disruption Between the Law and Its Application)] (101-128). Источно Сарајево: Српско удружење за кривичноправну теорију и праксу.

Јакулин, В. (2012). Казнена политика у Словенији (раскорак између очекивања и стварности) [Penal Policy in Slovenia (Disruption Between Expectations and Reality]. У: Бејатовић, С. ет ал. (ур.): Казнена политика (раскол између закона и ьегове примјене) [Penal Policy (Disruption Between the Law and Its Application] (129-138). Источно Сарајево: Српско удружење за кривичноправну теорију и праксу.

Кривични закон Босне и Херцеговине [КЗ БиХ], Службени гласник БиХ, број 3 (2003), 32 (2003) - испр., 37 (2003), 54 (2004), 61 (2004), 30 (2005), 53 (2006), 55 (2006), 8 (2010), 47 (2014), 22 (2015), 40 (2015), 35 (2018).

Кривични закон Брчко дистрикта БиХ [КЗ БДБиХ], Службени гласник Брчко дистрикта БиХ, број 33 (2013) и 26 (2016).

Кривични закон Федерације БиХ [КЗ ФБиХ], Службене новине ФБиХ, број 36 (2003), 37 (2003), 21 (2004), 69 (2004), 18 (2005), 42 (2010), 42 (2011), 59 (2014), 76 (2014) и 46 (2016).

Кривични законик Републике Српске [К3 РС], Службени гласник Републике Српске, број 64 (2017), 104 (2018) - одлука УС.

Манић, Ж. (2014). Примена и могућности методе анализе садржаја у соииологији (докторска дисертација) [Application and Possibilities of Method of Analysis of Content in Sociology (Doctoral Thesis)]. Београд: Универзитет у Београду, Филозофски факултет.

Миљевић, М. (2007). Методологија научног рада [Metodology of Scientific Paper]. Пале: Филозофски факултет Универзитета у Источном Сарајеву.

Misija OSCE-a u BiH [OSCE Mission to BiH]. (2018). Procjena potreba pravosuđa u procesuiranju korupcije kroz praćenje rada na krivičnim predmetima (ARC): Praćenje procesuiranja predmeta korupcije u BiH: prva procjena [Assessment of the Needs of Judiciary in Prosecution of Corruption Through Monitoring of Work on Criminal Cases (ARC): Monitoring of the Prosecution of Corruption Cases in BiH: The First Assesment]. Sarajevo: Misija OSCE-a u BiH. Доступно на: https://www.osce.org/bs/mission-to-bosnia-andherzegovina/373207?download=true, приступљено 30. 8. 2019.

Misija OSCE-a u BiH [OSCE Mission to BiH]. (2019). Procjena potreba pravosuđa u procesuiranju korupcije kroz praćenje rada na krivičnim predmetima (ARC): Praćenje procesuiranja predmeta korupcije u BiH: druga procjena [Assesment of the Needs of Judiciary in Prosecution of Corruption Through Monitoring of Work on Criminal Cases (ARC): Monitoring of the Prosecution of Corruption Cases in BiH: The Second Assesment]. Sarajevo: Misija OSCE-a u BiH. Доступно на: https://www.osce.org/bs/mission-to-bosnia-and-

herzegovina/417533?download=true, приступљено 30. 8. 2019.

Пресуда Суда БиХ, предмет број С1 2 К 02762418 К од 25. 1. 2018.

Пресуда Суда БиХ, предмет број С1 2 К 02354517 Ко од 30. 11. 2017. 
Пресуда Суда БиХ, предмет број С1 2 К 02668417 Ко од 20. 11. 2017.

Пресуда Суда БиХ, предмет број С1 2 К 02615517 К од 11. 9. 2017.

Пресуда Суда БиХ, предмет број С1 2 К 02606417 К од 24. 8. 2017.

Пресуда Суда БиХ, предмет број С1 2 К 02566617 К од 10. 7. 2017.

Пресуда Суда БиХ, предмет број С 12 К 02063216 К од 16. 6. 2017.

Пресуда Суда БиХ, предмет број С1 2 К 02516817 Ко, од 12. 5. 2017.

Пресуда Суда БиХ, предмет број С1 2 К 01790115 К од 5. 5. 2017. и Пресуда Суда БиХ, предмет број С1 2 К 01790117 Кжк од 13. 4. 2018.

Пресуда Суда БиХ, предмет број С1 2 К 02310916 К од 10. 3. 2017.

Пресуда Суда БиХ број С 12 К 01479214 К од 7. 3. 2017.

Пресуда Суда БиХ, предмет број С1 2 К 02445917 К од 28. 2. 2017.

Пресуда Суда БиХ, предмет број С1 2 К 01937315 К од 10. 1. 2017.

Пресуда Суда БиХ, предмет број С 12 К 02383816 К од 29. 12. 2016.

Пресуда Суда БиХ, предмет број С1 2 К 02361716 Ко од 8. 11. 2016.

Пресуда суда БиХ, предемт број С1 2 К 01538414 К од 14. 9. 2016. и Пресуда Суда БиХ, предмет број С1 2 К 00608714 Кжк од 22. 5. 2017.

Пресуда Суда БиХ, предмет број С1 2 К 02140116 К од 11. 4. 2016.

Пресуда Суда БиХ, предмет број С1 2 К 02129216 К 4. 4. 2016.

Пресуда Суда БиХ, предмет број С1 2 К 01933215 К од 27. 8. 2015.

Пресуда Суда БиХ, предмет број С1 2 К 01375614 К од 16. 6. 2015. и Пресуда Суда БиХ, предмет број С1 2 К 01375615 Кж 3 10. 3. 2016.

Радуловић, В., Ћаловић, В. (S. а.). Анализа судских пресуда за кривична дјела са елементима организованог криминала: Превениија или подстицанје организованог криминала [Analysis of Court Judgments for Criminal Offenses with Elements of Organized Crime: Prevention or Inciting to Organized Crime]. Подгорица: Мрежа за афирмацију невладиног сектора - MANS. Доступно на: http://www.mans.co.me/wp-content/uploads/mans/publikacije/iza-statistike3/ Statistika3MNf.pdf, приступљено 30. 8. 2019.

Рашовић, М. (2017). Судска пракса као извор права [Court Case Law as Source of Rights]. Матица, 18(70), 117-172.

Рисимовић, Р., и Коларић, Д. (2016). Редовно одмеравање казне [Regular Determination of Penalty]. Теме, 11(1), 1-14.

Savjet Ministara [Council of Ministers]. (2016). Procjena prijetnje od organizovanog kriminala u Bosni i Hercegovini [Assessment of Organized Crime Threat in Bosnia and Herzegovina]. Sarajevo: Savjet ministara. Доступно на: http://www.msb.gov.ba/PDF/OCTA_BiH_2016_Final_usvojena_08032017.pdf, приступљено 25. 4. 2019.

Simović, M., Simović, V. (2016). Krivično procesno pravo [Criminal Procedural Law]. Bihać: Pravni fakultet Univerziteta u Bihaću.

Симовић, М., Шикман, М. (2017). Кривичноправно реаговаъе на тешке облике криминалитета [Criminal Procedural Reaction to Serious Crimes]. Бања Лука: Правни факултет Универзитета у Бањој Луци.

Симовић, М., Шикман, М. (2018). Кривичнопроцесне радње у сузбијању тешких облика криминалитета [Criminal Procedural Actions in Fight Against Serious Crimes]. Ревија за криминологију и кривично право, 56(1), 9-32

Стојановић, 3. (2009). Кривично право: општи део [Criminal Law: General Part]. Београд: Правна књига.

Стојановић, 3. (2012). Казнена политика - раскол између закона и његове примјене [Penal Policy - Disruption Between the Law and Its Application]. У: Бејатовић, С. ет ал. (ур.): Казнена политика (раскол између закона и његове примјене) [Penal Policy (Disruption Between the Law and Its Application)] (7-22). Источно Сарајево: Српско удружење за кривичноправну теорију и праксу. 
Стојановић, 3. (2018). Коментар Кривичног законика: према стағу Кривичног законика од 1. марта 2018. године и према стању законодавства од 13. децембра 2016. године [Commentary to the Criminal Code: According to the Criminal Code of 1 March 2018 and Legislation of 13 December 2016]. Београд: Службени гласник.

Стојановић, 3., Коларић, Д. (2014). Кривичноправно сузбијағе организованог криминалитета, тероризма и корупиије [Criminal Justice Fight Against Organized Crime, Terrorism and Corruption]. Београд: Правни факултет Универзитета у Београду.

Sud Bosne i Hercegovine [Sud BiH], internet stranica: http://www.sudbih.gov.ba/

Sud BiH [Court of Bosnia and Herzegovina]. (2017). Procesuiranje predmeta korupcije $i$ terorizma pred Sudom Bosne i Hercegovine [Prosecution of Corruption and Terrorism Cases before the Court of Bosnia and Herzegovina]. Sarajevo: Sud BiH. Доступно на: http://www.sudbih.gov.ba/stranica/53/pregled, приступљено 2. 8. 2019.

United Nations Convention against Transnational Organized Crime, adopted by the General Assembly of the United Nations on 15 November 2000. Доступно на: $h t t p: / / w w w . u n o d c . o r g / p d f / c r i m e / a \_r e s \_55 /$ res5525e.pdf

USAID (2017). Analiza procesuiranja koruptivnih krivičnih djela u Bosni $i$ Hercegovini kroz prikaz odabrane sudske prakse [Analysis of Prosecution of Corruptive Criminal Offenses in Bosnia and Herzegovina Through an Overview of Selected Court Case Law]. Sarajevo: USAID. Доступно на: https://usaidjp.ba/assets/files/publication/1516868003-analiza-procesuiranjakoruptivnih-krivicnih-djela-u-bih.pdf, приступљено 30. 7. 2019.

USAID i Beogradski centar za ljudska prava. (2008). Borba protiv organizovanog kriminala u Srbiji - zakonodavstvo i praksa. Beograd: Beogradski centar za ljudska prava. Доступно на: http://bgcentar.org.rs/bgcentar/wp-content/uploads/ 2013/10/Borba-protiv-organizovanog-kriminala-u-srbiji-zakonodavstvo-i-praksa2008.pdf, приступљено 30. 8. 2019.

Faktor.ba (20.11.2015.). Sud BiH: Dilerima iz Čapljine 42 mjeseca zatvora. Доступно на: https://www.faktor.ba/vijest/sud-bih-dilerima-iz-capljine-42mjeseca-zatvora-176804, приступљено 17. 2. 2019.

Филиповић, Љ. (2017). Квалитет оптужница и пресуда у Босни и Хериеговини као фактор ефикасног прочесуирања кривичних дјела корупиије [Quality of Intictments and Judgments in Bosnia and Herzegovina as an Element of Prosecution of Criminal Offenses of Corruption]. Сарајево: Аналитика Центар за друштвена истраживања.

Центар за сигурносне студије [Centre for Security Studies]. (2014). Сmyдиja o организованом криминалитету у Босни и Хериеговини [Study on Organized Crime in Bosnia and Herzegovina]. Сарајево: Центар за сигурносне студије.

Council Framework Decision 2008/841/JHA of 24 October 2008 on the fight against organised crime. Доступно на: http://eur-lex.europa.eu/Lex UriServ/LexUriServ. do? uri=OJ:L:2008:300:0042:0045:EN:PDF, приступљено 15. новембра 2014.

Consultative Council Of European Judges (CCJE) (2008). Opinion $\mathrm{N}^{\circ} 11$ (2008) On "The Quality Of Judicial Decisions". Strasbourg: Council of Europe. Доступно на: https://rm.coe.int/16807482bf, приступљено 7. 4. 2019.

Consultative Council Of European Judges (CCJE) (2017). Opinion $N^{\circ} 20$ (2017) The Role Of Courts With Respect To The Uniform Application Of The Law. Strasbourg: Council of Europe. Доступно на: https://rm.coe.int/opinionno-20-2017-on-the-role-of-courts-with-respect-to-the-uniform-a/16807661e3, приступьено 7. 4. 2019. 
Шикман, М. (2019). Организовани криминалитет - криминалистичка и судска пракса у Босни и Херцеговини [Organized Crime - Criminal and Court Case Law in Bosnia and Herzegovina]. У: Бејатовић, С. и Симовић, М. (ур.): Казнена политика и превенција криминалитета [Penal Policy in Prevention of Crimes] (369-392). Требиње: Српско удружење за кривичноправну теорију и праксу.

Шкулић, М. (2015). Организовани криминалитет - појам, појавни облиции, кривична дела и кривични поступак [Organized Crime - Concept, Forms of Appearance, Criminal Offenses and Criminal Proceedings]. Београд: Службени гласник.

\title{
АДЕКВАТНОСТ КАЗНЕНЕ ПОЛИТИКЕ У КРИВИЧНИМ ПРЕДМЕТИМА ОРГАНИЗОВАНОГ КРИМИНАЛИТЕТА
}

\author{
Миодраг Симовић ${ }^{1}$, Миле Шикман ${ }^{2}$ \\ ${ }^{1}$ Уставни суд БиХ, Универзитет у Бањој Луци, Правни факултет, \\ Босна и Херцеговина \\ ${ }^{2}$ МУП Републике Српске, Универзитет у Бањој Луци, Правни факултет, \\ Босна и Херцеговина
}

\section{Резиме}

Основна сврха кривичног права је обављање заштитне функције прописивањем кривичних дјела и кривичних санкција за та дјела путем кривичног закона. Његова примјена, која се утврђује у кривичном поступку, доводи до изрицања кривичних санкција због учињеног кривичног дјела. Да би се остварила сврха кажњавања, кривичне санкције морају бити засноване на сразмјерности јачини опасности за личне слободе и права човјека, те друге основне вриједности, као и њихова адекватна примјена у кривичном поступку.

Организовани криминалитет спада у тешке облике криминалитета. Због тога су инкриминисана она понашања која се тичу криминалног удруживања за вршење кривичних дјела која су типична за ову врсту криминалне дјелатности. Организовани криминалитет је присутан у различитим облицима испољавања у Босни и Херцеговини. Такође, о организованом криминалитету у БиХ постоји обимна судска пракса с обзиром на то да се од 2003. године воде кривични поступци за ова кривична дјела, пред судским инстанцама свих нивоа и надлежности.

Ова питања нису довољно разјашњена и да би адекватност казнене политике у кривичним предметима организованог криминалитета била примјењива, постоји сложено питање анализе законодавног оквира организованог криминалитета и анализе судске праксе када су у питању ова кривична дјела. Циљ овог рада је сагледавање адекватности кривичноправних инкриминација организованог криминалитета, с једне стране, и адекватности изречених кривичноправних санкција, с друге стране. Због тога се и говори о казненој политици законодавца и казненој политици судова када је у питању организовани криминалитет.

Када је ријеч о прописивању кривичних дјела организованог криминалитета, ово је и једно од најсложенијих питања. Како се ради о најтежим кривичним дјелима, не постоји спор око неопходности прописивања ових понашања као кривичних дјела. Оно о чему се може дискутовати јесте начин њиховог прописивања.

Када је у питању судска пракса у предметима организованог криминалитета, она представља примјену законских прописа и доношења одлука у складу са 
прописима. Како је законодавац усвојио систем релативно одређених казни, гдје су казне за кривична дјела организованог криминалитета прописане у веома широком распону, од великог значаја је судско одмјеравање казне. Квалитетна судска одлука и непристрасно разматрање свих питања (чињеничних и правних) саставни су дијелови адекватности казнене политике у предметима организованог криминалитета.

У овом раду је извршена анализа садржаја судских пресуда у кривичним предметима организованог криминалитета. Подаци су прикупљени из судских одлука у одабраним предметима организованог криминалитета у периоду 20152018. године који су вођени пред Судом БиХ. Предметном анализом изабрана су она кривична дјела која су типична за дјеловање организованих криминалних група.

Након прикупљања података, приступило се њиховој анализи. Тако су анализом утврђене и анализиране сљедеће категорије: врста и висина изречене кривичне санкције за кривична дјела организованог криминалитета, општа правила одмјеравања казне (отежавајуће и олакшавајуће околности), те коришћење споразума о признању кривице, као посебног института поједностављене форме поступања у кривичном поступку.

Када сагледамо све одговоре на постављено питање о адекватности казнене политике у кривичним предметима организованог криминалитета, онда можемо закључити да она није у потпуности усаглашена. Очигледан је несклад између казнене политике законодавца и казнене политике Суда БиХ о овом питању. Због тога је потребно усагласити судску праксу са казненом политиком законодавца и поставити реалнија очекивања од стране законодавца приликом инкриминације наведених понашања. Потребно је адекватније одмјеравање казни тако што би све околности под којима је учињено кривично дјело биле узете у обзир у њиховој укупности, укључујући и отежавајуће околности, као и заузимање јасног става шта се сматра организованим криминалитетом. Требало би да законодавац узме у разматрање актуелну судску праксу, те размотри могућност још прецизнијег прописивања понашања која се сматрају организованим криминалитетом, за која би свакако требало задржати строгу казнену политику. 